\title{
Sunitinib Reduces Acute Myeloid Leukemia Clonogenic Cells in Vitro and Has Potent Inhibitory Effect on Sorted AML ALDH+ Cells
}

\author{
Asad M. Ilyas ${ }^{1,2}$, Youssri Ahmed ${ }^{2,3,4}$, Mamdooh Gari1, Mohammed H. Alqahtani1, \\ Taha A. Kumosani ${ }^{2,3}$, Abdulrahman L. Al-Malki'2,5, Khalid O. Abualnaja ${ }^{2,5}$, \\ Saad H. S. Albohairi' ${ }^{6}$, Adeel G. A. Chaudhary ${ }^{1}$, Farid Ahmed1 ${ }^{*}$ \\ ${ }^{1}$ Centre of Excellence in Genomic Medicine Research, King Abdulaziz University, Jeddah, Saudi Arabia \\ ${ }^{2}$ Department of Biochemistry, Faculty of Science, King Abdulaziz University, Jeddah, Saudi Arabia \\ ${ }^{3}$ Production of Bioproducts for Industrial Applications Research Group, Experimental Biochemistry Unit, King \\ Fahd Medical Research Center, King Abdulaziz University, Jeddah, Saudi Arabia \\ ${ }^{4}$ Microbial Biotechnology Department, National Research Center, Cairo, Egypt \\ ${ }^{5}$ Bioactive Natural Products Research Group, Experimental Biochemistry Unit, King Fahd Medical Research \\ Center, King Abdulaziz University, Jeddah, Saudi Arabia \\ ${ }^{6}$ King Abdulaziz University Hospital, Jeddah, Saudi Arabia

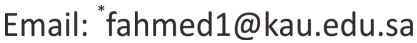

Received 21 January 2016; accepted 28 March 2016; published 31 March 2016

Copyright (C) 2016 by authors and Scientific Research Publishing Inc.

This work is licensed under the Creative Commons Attribution International License (CC BY). http://creativecommons.org/licenses/by/4.0/

(c) (i) Open Access

\section{Abstract}

Sunitinib is an orally administered, multi-target tyrosine kinase inhibitor that has been approved by the FDA for the treatment of renal cell carcinoma and imatinib resistant gastro-intestinal tumors. Anti-leukemic activity of sunitinib has been examined in early clinical trials with limited success. However, recent trials on acute myeloid leukemia (AML) patients carrying FLT3 mutations have shown promising results. Effects of sunitinib on leukemic clonogenic cells and potential leukemic stem cells have not been examined so far. We analyzed the anti-proliferative and apoptotic properties of sunitinib on AML-derived cell lines. We also tested the effect of sunitinib on AML patient derived clonogenic cells (AML-CFC), as well as flow-sorted potential leukemic progenitors. Peripheral blood or bone marrow samples were obtained from newly diagnosed AML patients and flow sorted for $\mathrm{CD}^{+} 4^{+} \mathrm{CD} 33^{+}$or $\mathrm{ALDH}^{+}$cells. Umbilical cord blood derived $\mathrm{CD}^{2} 4^{+}$cells were used as normal controls. Sunitinib induced growth arrest and apoptosis in AML derived cell lines. In addition, $7 \mu \mathrm{M}$ sunitinib induced $75 \%$ reduction of AML-CFC as compared to DMSO treated control $( \pm 6.79 \% ; n=4)$. In contrast, $7 \mu \mathrm{M}$ sunitinib treatment of umbilical cord blood derived normal $\mathrm{CD}_{4}{ }^{+}$cells showed $29 \%$ reduction in AML-CFC $( \pm 6.77 \% ; n=5)$. Treatment of $\mathrm{ALDH}^{+}$cells sorted from 2 AML cases and $\mathrm{CD}_{34}{ }^{+} \mathrm{CD}_{133}{ }^{+}$cells from one patient showed reduction of AML-CFC on treatment with sunitinib. Our study highlighted a potent anti-proliferative and proapoptotic 
effect of sunitinib on AML cell lines, AML patient derived clonogenic cells and potential leukemic stem cells.

Keywords

Acute Myeloid Leukemia, Sunitinib, Tyrosine Kinase Inhibitor, AML-CFC, Leukemic Stem Cells

\section{Introduction}

Acute myeloid leukemia (AML) is a clonal proliferative disorder of the myeloid progenitors that results in an accumulation of immature myeloid cells in the bone marrow and peripheral blood. Substantial improvement in the outcome of AML patients is seen during the recent times, which is mainly due to the development of risk-stratified treatment approaches to patient management [1]. However, treatment of elderly AML patients, patients carrying mutations in FLT3 and those with complex cytogenetic abnormalities and monosomies still remain challenging. In this regard, development of novel targeted therapeutic approaches is crucial for improving the clinical outcome of AML subsets [2].

Sunitinib is a multi-targeted tyrosine kinase inhibitor (TKI) that targets platelet-derived growth factor receptors (PDGFRs), vascular endothelial growth factor receptors (VEGFRs) and other constitutively active kinases like c-KIT. Sunitinib has been approved by the United States Food and Drug Administration (FDA) for the treatment of metastatic renal cell carcinoma (mRCC) and gastrointestinal stromal tumor (GIST) [3]. Sunitinib has also been shown to decrease the phosphorylation of wild type fms-related tyrosine kinase (FLT3) and internal tandem duplications (ITDs) using in vitro and in vivo AML models [4] [5]. In clinical trials evaluating safety and efficacy in AML patients, sunitinib showed molecular and clinical responses, however, this was transient and associated with significant toxicities [6]. Use of sunitinib in combination with conventional chemotherapy had shown promising results. Combination of sunitinib with AraC or Daunorubicin demonstrated synergistic inhibition of FLT3-ITD positive AML cells [7]. A recent phase I/II study in older AML patients with FLT3 mutations studied addition of sunitinib to standard induction and consolidation chemotherapy, followed by maintenance on sunitinib. In this study, a $25 \mathrm{mg} /$ day dose of sunitinib was well tolerated and complete remission was achieved in 59\% AML patients irrespective of the type of FLT3 mutation [8]. In the present study, we have evaluated the activity of sunitinib on AML cell lines and clonogenic cells from primary AML samples and potential AML stem cells subpopulation.

\section{Material and Methods}

\subsection{Materials}

A stock solution of $20 \mathrm{mM}$ sunitinib malate (Sigma-Aldrich, USA) was prepared by dissolving in the dimethyl sulfoxide (DMSO, Sigma-Aldrich, USA) and stored at $-20^{\circ} \mathrm{C}$. Further dilutions were done in DMSO. Cell-Titer blue viability kit (Promega, UK) was used to study the effect of sunitinib on cell line viability. CD34-PE, Annexin V450 and 7-AAD antibodies were purchased from the BD (BD biosciences, USA). CD34 Microbead kit was obtained from Miltenyi (Miltenyi Biotech, Germany). Propidium iodide and RNase A were purchased from Sigma (Sigma-Aldrich, USA). Lymphoprep and MethoCult ${ }^{\mathrm{TM}}$ (H4434 and H4100) were purchased from Stem Cell Technologies (Stem Cell Technologies, Canada).

\subsection{Sample Collection and Isolation of CD34+ Cells}

Umbilical cord blood (UCB) samples from normal deliveries and primary AML patient bone marrow (BM) or peripheral blood (PB) samples were collected after informed consent. This study has been approved by the institution review board in accordance with the Helsinki declaration. Mononuclear cells (MNCs) were isolated by density gradient centrifugation from the UCB/AML samples using Lymphoprep (Stem Cell Technologies, Canada). UCB was diluted 1:2 with sterile 1× PBS (Gibco, Life Technologies, USA) and layered on the Lymphoprep. Following centrifugation at $750 \mathrm{~g}$ for 30 mins, mononuclear cells were collected from the gradient. CD34 ${ }^{+}$ 
cells were enriched from the MNCs by positive selection using CD34 Microbead kit according to the manufacturer's protocol (Miltenyi Biotec, Germany). Isolated CD34 ${ }^{+}$cells were checked for their purity by labelling with anti-CD34-PE on the BD FACS Aria III (BD biosciences, USA) flow cytometer. In this study, we included only samples having purity above $95 \%$. The enriched samples were counted for their viability and cryo preserved in fetal bovine serum with 10\% DMSO and stored in liquid nitrogen for next use.

\subsection{Cell Culture}

K562 (erythroleukemia), HL60 (acute promyelocytic leukemia) and NB4 (acute promyelocytic leukemia) cells were cultured in Roswell Park Memorial Institute (RPMI) medium (Gibco, Life Technologies, USA) supplemented with 10\% FBS (Lonza, USA) and incubated in humidified $5 \% \mathrm{CO}_{2} 37^{\circ} \mathrm{C}$ incubator. All the cell lines were purchased from Cell Lines Service (CLS GmbH, Germany). AML mononuclear cells and sorted human hematopoietic stem/progenitors cells were cultured in serum free expansion media (Stem cell Technologies, Canada) for drug assays.

\subsection{Cell Proliferation Assay}

Cell proliferation assay was performed using Cell-Titer blue cell viability kit. Briefly, $1 \times 10^{4}$ cells were incubated in a quadruplicate with different doses of sunitinib in a 96-well plate with a total volume of $100 \mu \mathrm{L}$ medium. DMSO treated cells served as control. After 48 hours of incubation, $20 \mu \mathrm{L}$ of cell titer blue reagent was added and fluorescence was recorded at 560/590 nm on a microplate reader (Spectramax i3, Molecular Devices, USA) after $2 \mathrm{hr}$ of incubation at $37^{\circ} \mathrm{C}$. Percentage cell viability was calculated as fluorescence value of the treated cells/fluo-rescence value of the control $\times 100$. At least three independent experiments were performed.

\subsection{Detection of Apoptosis}

Annexin V assay was performed to detect apoptotic cells. Briefly, $2 \times 10^{5}$ cells were plated in a 6-well plate and treated with various concentrations of sunitinib including DMSO treated control and incubated for $48 \mathrm{hrs}$. The cells were harvested and stained with Annexin V450 and 7-AAD. The stained samples were analyzed by acquiring 10,000 cells using BD FACS Aria III.

\subsection{Cell Cycle Analysis}

Cells were seeded in a 6-well plate at density of $5 \times 10^{5}$ cells per well and treated with various doses of sunitinib. After $48 \mathrm{hrs}$, cells were collected and fixed with ice-cold ethanol and kept at $-20^{\circ} \mathrm{C}$ for 1 hour. Cells were washed and then stained with propidium iodide (PI) staining solution (PI $40 \mu \mathrm{g} / \mathrm{ml}$, RNase $20 \mu \mathrm{g} / \mathrm{ml}$ ). Flow cytometric analysis was performed by acquiring 20,000 doublet-excluded cells using BD FACS Aria III sorter.

\subsection{Aldefluor Assay and Flow Cell Sorting}

Aldehyde dehydrogenase (ALDH) activity was evaluated in AML patient MNCs as per manufacturer's instruction (Aldefluor, Stem Cell Technologies, Canada). DEAB was added to create a negative control. Co-staining with anti-CD34-VioBlue (Miltenyi Biotech, Germany) was done in some samples. Stained samples were then analyzed and isolated by sorting ALDH ${ }^{+}$cells (BD FACS Aria III).

\subsection{CFC Assay}

Colony forming cell (CFC) assay was performed by plating cells following $24 \mathrm{~h}$ sunitinib or DMSO (Control) treatment. AML-CFC assays were performed by plating un-sorted AML cells at 20,000 - 60,000 cells $/ \mathrm{ml}$ or $\mathrm{ALDH}^{+} / \mathrm{CD}^{+} 4^{+}$cells at 10,000 cells/ml in Methocult as described [9] [10]. The colonies were evaluated after 10 - 14 days. CFC assay for drug treated normal CD34 ${ }^{+}$cells were performed by plating 1000 cells/ml Methocult and evaluated after 12 days.

\subsection{Statistical Analysis}

Cell proliferation curves were generated using Graphpad Prism (Graphpad Software Inc, USA). Data was presented as mean \pm SEM. Unpaired two-tailed Student's $t$-test was used for all in vitro cell line experiments and 
AML-CFC assays. A $p<0.05$ was considered significant. Mann-Whitney $U$ test was used to determine significant differences between two individual AML patient groups.

\section{Results}

\subsection{Anti-Proliferative Effect of Sunitinib in Different Leukemia Cell Lines}

In order to explore the antiproliferative effects of sunitinib (Figure 1(a)), on AML cells, human HL60, K562 and NB4 cell lines were cultured with increasing concentrations of sunitinib. Cell proliferation and viability was assessed using the Cell-Titre Blue Kit after $48 \mathrm{~h}$ treatment. As represented in Figure 1(b), sunitinib inhibited HL60, K562 and NB4 cell proliferation in a dose-dependent manner with IC $_{50}$ values of 5.7, 4.4 and $7.3 \mu \mathrm{M}$ respectively. In order to determine the precise mechanism for the anti-proliferative action of sunitinib, annexin $\mathrm{V}$ staining and cell cycle distribution profile was studied. As shown in Figure 1(c) \& Figure 1(d), dose dependent increase in annexin $\mathrm{V}$ positive cells was observed in sunitinib-treated cells, suggesting apoptosis as the reason for anti-proliferative action of sunitinib on AML cell lines. Additionally, as shown in Figure 1(e), exposure of AML cells to sunitinib for $48 \mathrm{~h}$ led to an increase in the number of sub-G1 population of cells representing apoptotic cells. Increasing doses of sunitinib results in a concomitant decrease in the proportion of cells in the S phase for all cell lines tested, indicating a decrease in the proliferation of cells.

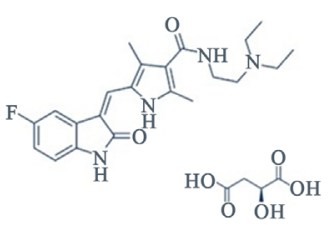

Sunitinib malate

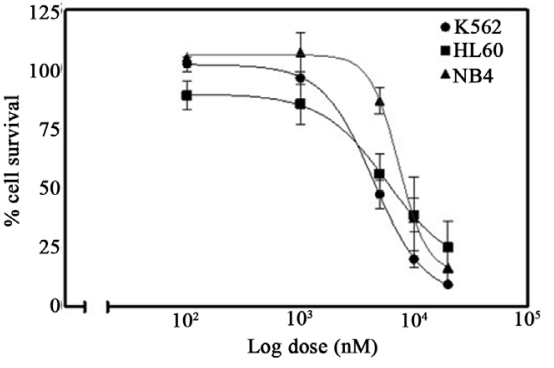

(b)

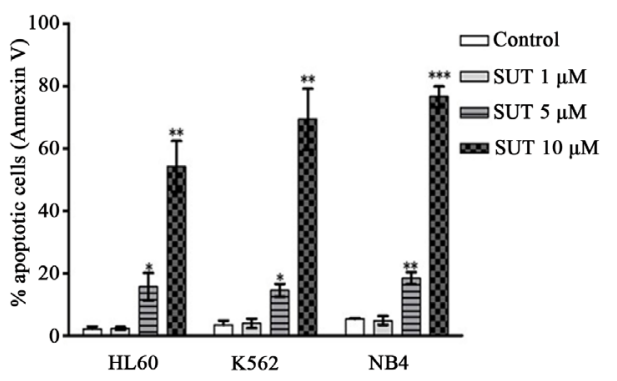

(c)

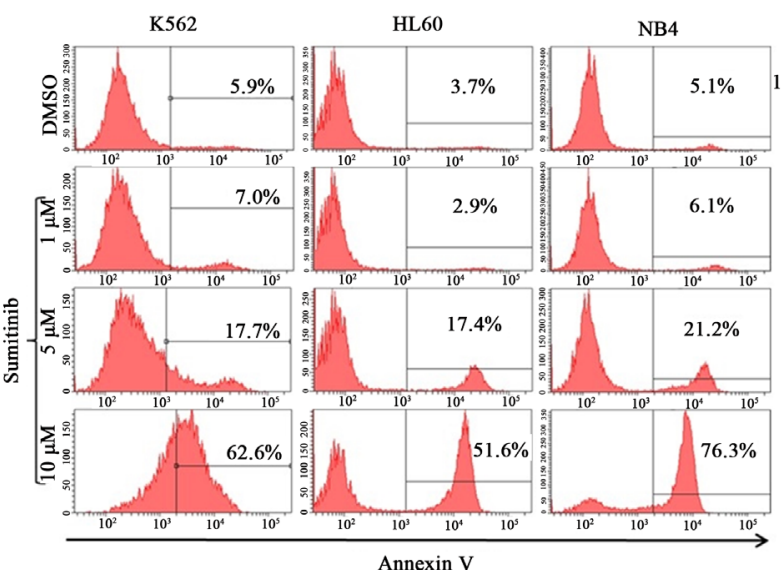

(d)

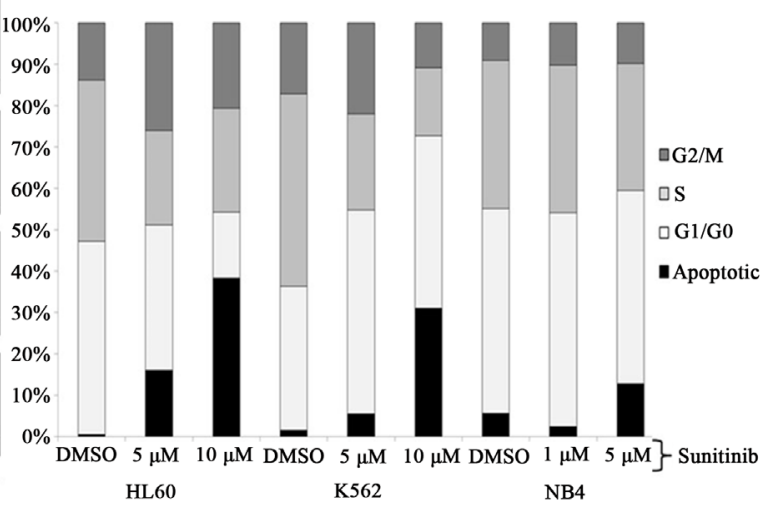

(e)

Figure 1. Antiproliferative effect of Sunitinib on AML cells lines. (a) Chemical structure of Sunitnib malate; (b) Cell proliferation assay performed using Cell-Titre Blue reagent at $48 \mathrm{~h}$ demonstrated a dose-dependent antiproliferative effect on AML cell line K562, NB4 and HL60. The data is represented as mean \pm SEM of three independent experiments. Curve fitting was performed by non-linear regression using log (inhibitor) vs. response-variable slope (four parameters) using Graphpad Prism. The $\mathrm{IC}_{50}$ for sunitinib in K562 was $4.4 \mu \mathrm{M}$, in HL60 was $5.7 \mu \mathrm{M}$ and in NB4 was $7.3 \mu \mathrm{M}$; (c) Mean \pm SEM of three independent experiments showing percentage apoptotic cells in different AML cell lines upon treatment with increasing dose of sunitinib. ' represents $p<0.05$, ${ }^{* *}$ represents $p<0.01$, ${ }^{* * *}$ represents $p<0.001$ compared to the control; (d) Apoptosis assays performed using annexin V staining shows a dose dependent increase in apoptosis with sunitinib in all AML cell lines and $48 \mathrm{~h}$. Analysis was done on BD FACS Aria III flow cytometer; e) Cell cycle analysis of HL60, K562 and NB4 cells were performed by staining the cells with propidium iodide and analyzed with the flow cytometer. 


\subsection{Effect of Sunitinib on Primary AML Clonogenic Cells}

In order to evaluate the effect of sunitinib on primary AML patient derived leukemic cells, AML-BM or PB samples were incubated in the presence of $7 \mu \mathrm{M}$ sunitinib or DMSO for $24 \mathrm{~h}$ before performing AML-CFC assay. Normal UCB CD34 ${ }^{+}$was used for comparison. As shown in Figure 2(a), treatment with $7 \mu \mathrm{M}$ sunitinib resulted in a $75 \%$ reduction in mean AML-CFC as compared to DMSO treated control $( \pm 6.8 \% ; n=4)$. Treatment of normal UCB CD34 ${ }^{+}$cells with $7 \mu \mathrm{M}$ sunitinib showed only $29 \%$ reduction $( \pm 6.77 \%$; $n=5)$. ALDH activity was checked in 20 newly diagnosed AML samples. Patients with blast count $>20 \%$ showed higher ALDH activity as compared to patients with $<20 \%$ blasts ( $\mathrm{U}=6.0, p=0.007$, Figure 2(b)). In order to check the effect of sunitinib on potential leukemic stem cells, we sorted $\mathrm{ALDH}^{+} \mathrm{CD} 34^{+}$and $\mathrm{ALDH}^{-}$cells from two AML patients and plated them in clonogenic assay with or without $7 \mu \mathrm{M}$ sunitinib. ALDH ${ }^{-}$cells did not show any CFC growth, however, colonies were detected only in $\mathrm{ALDH}^{+}$sorted cells. In the presence of sunitinib, $\mathrm{ALDH}^{+} \mathrm{AML}$ cells lost the clonogenic potential in both AML samples tested (Figure 2(d), Figure 2(e)). From another AML sample showing $\mathrm{CD}_{3} 4^{+} \mathrm{CD} 133^{+}$cells, various subpopulations were sorted out as indicated in Figure 2(d). Only cells expressing CD34 formed colonies. Treatment of $\mathrm{CD}_{3} 4^{+} \mathrm{CD} 133^{+}$sorted cells and $\mathrm{CD} 34^{+} \mathrm{CD} 133^{-}$cells with sunitinib reduced the number of colonies (Figure 2(f)).

\section{Discussion}

Activating mutations in RTKs are common in AML and have adverse clinical outcome. FLT3 mutations that in-

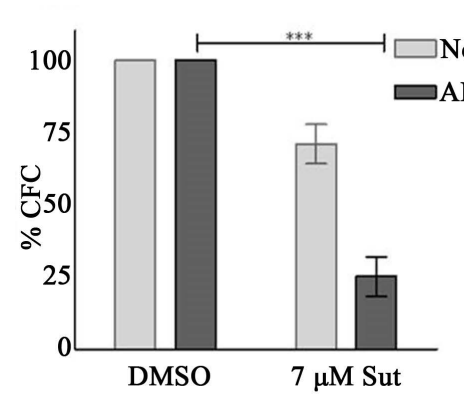

(a)

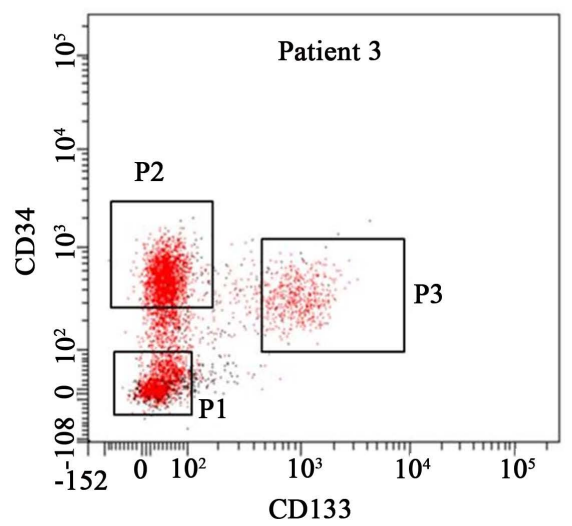

(d)

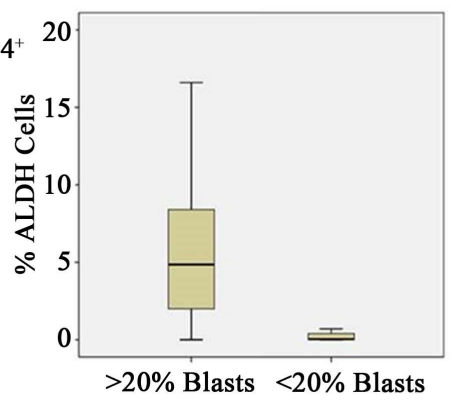

(b)

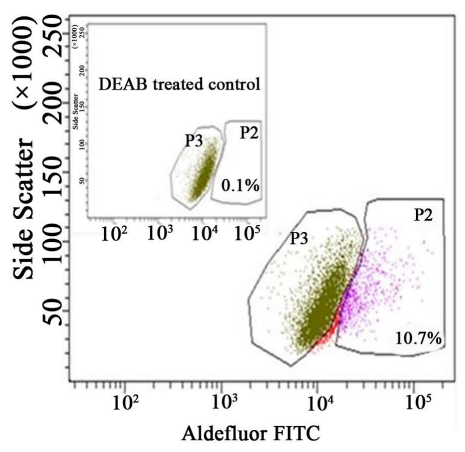

(c)

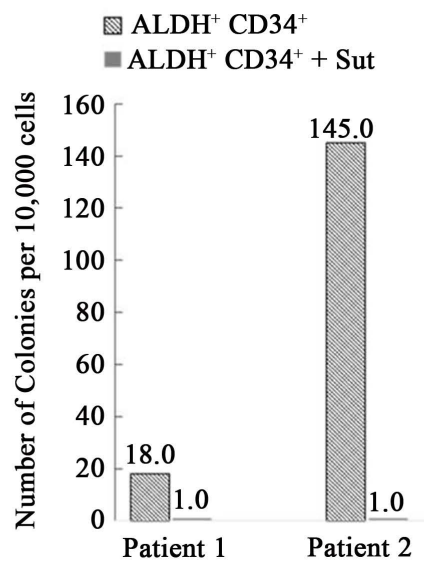

(e)

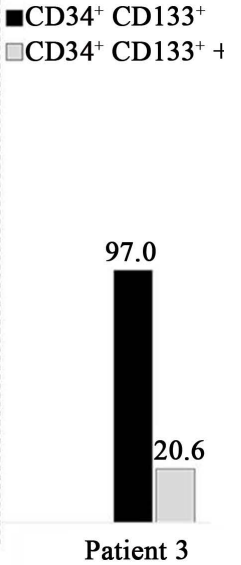

(f)

Figure 2. Effect of sunitinib on clonogenic cells (a) Sunitinib (Sut) effectively reduces CFC derived from primary AML samples. Treatment of normal CD34 ${ }^{+}$cells showed weaker inhibition of CFC; (b) Expression of ALDH using aldefluor staining in AML patients grouped according to blast percentage. Mann-Whitney U test showed patients with $>20 \%$ blasts have higher ALDH activity ( $p=0.007)$; (c) $\mathrm{ALDH}^{+}$cells were sorted from 2 different AML samples $(\mathrm{n}=2)$ generated colonies in CFC assay(e); (d) Sorting of potential leukemic stem cells from patient 3 demonstrated clonogenic potential only in $\mathrm{CD}^{+} 4^{+} \mathrm{CD} 133^{+}$cells P3 and CD34 ${ }^{+}$CD133 ${ }^{+}$cells (P2); (f) $7 \mu \mathrm{M}$ sunitinib eradicates these leukemic CFCs. 
clude internal tandem duplication (FLT3-ITD) and the tyrosine kinase domain mutation (FLT3-TKD), are found in almost 30\% of newly diagnosed AML [11]. These mutations confer an adverse prognosis in AML [12]. Mutations in the KIT receptor gene have been reported in 3\% - 15\% of AML cases [13] [14] and with a significantly higher proportion in core binding factor AML (CBF-AML) [15]. KIT mutations confer adverse prognosis to CBF-AML [16] [17]. Owing to the high frequency of RTK mutations and poor clinical outcome there has been continuous efforts to develop targeted inhibitors of RTK. Many compounds have entered clinical trials and have demonstrated varying efficacies either as single agents or combination with conventional chemotherapies [8] [18] [19] [20]. Sunitinib is an orally available multi-targeting TKI, mainly targeting VEGFR, PDGFR, CD117 (c-KIT) and FLT3 [21]. Although clinical studies of sunitinib have shown some promising results, the effect of sunitinib on clonogenic leukemic cells and $\mathrm{ALDH}^{+}$potential leukemic stem cells has not been evaluated so far. In this paper we are able to demonstrate potent antiproliferative effect of sunitinib on three myeloid leukemia cell lines (K562, HL-60 and NB4) with varying IC $_{50}$ values. The slight differences in the IC $_{50}$ values from previously published reports in K562 and NB4 cells [22] [23], could be due to different times points for studying viability. We were able to demonstrate that sunitinib induces dose-dependent apoptosis in AML cell lines. Similar findings were reported earlier in other leukemic and non-leukemic cell lines [22] [24].

To study the effect of sunitinib on clonogenic AML cells, we evaluated primary AML patient with $>20 \%$ blasts in CFC assay. Impairment of clonogenic survival was more pronounced in AML cells as compared to umbilical cord blood derived normal CD34 cells. The main reason for preferential killing of AML cells over normal CD34 cells by Sunitinib could be dependence of AML cells on multiple RTKs for proliferation. A previous study of in vitro FLT3 inhibition in AML showed no clear relationship between mRNA levels of FLT3 and response to RTK inhibitors lestaurtinib and PKC412 [25]. This non-concordance of response to FLT3 inhibitors might be due to other RTKs involved in AML cell signaling. In order to look for potential stem cell markers in AML samples, a number of groups have described $\mathrm{ALDH}^{+}$cells to be enriched in AML stem cells [26] [27]. Analysis of $\mathrm{ALDH}^{+}$cells was possible in $24 \mathrm{AML}$ samples but sufficient number of cells could be sorted from only 2 samples for in vitro targeting experiments with sunitinib. Higher expression of ALDH was observed in patients having blast \% more than 20. Additionally, ALDH expression correlated with high CD34\% (data not shown). In view of the reports of presence of leukemic stem cells in ALDH-bright or ALDH-intermediate blasts [27] [28], our experiments were aimed at targeting these potential LSC using sunitinib. Our results highlight the possibility of elimination of potential LSC by sunitinib. The mechanism of sunitinib action on ALDH positive AML cells could not be elaborated in this limited study. In the third patient that was highly positive for CD34 and co-expressed CD133, only cells that expressed CD34 formed colonies. CD $34^{+} \mathrm{CD} 133^{+}$cells formed colonies with a higher frequency than the $\mathrm{CD} 34^{+} \mathrm{CD} 133^{-}$cells indicating a more primitive clonogenic feature. Although a functional hierarchy among the $\mathrm{CD}_{3} 4^{+} \mathrm{CD} 133^{+}$and $\mathrm{CD} 34^{+} \mathrm{CD} 133^{-}$has been demonstrated in UCB derived normal cells, so far no study has demonstrated any such functional hierarchy in AML samples [29] [30]. While our in vitro results do indicate a functional hierarchy in the ability to form leukemic colonies, in vivo studies are needed to fully characterize this hierarchy.

\section{Conclusion}

Our study highlights the relevance of TKI inhibitors in targeting clonogenic AML cells and potential AML stem cells. Our data supports the evidence of functional hierarchy in ALDH expressing AML cells. Moreover, our data demonstrate strong activity of sunitinib on potential LSC candidates in vitro.

\section{Acknowledgements}

The authors would like to thank technical staff of the Center of Excellence in Genomic Medicine Research, Manal Al-Oteibi and Fatima Kadi, for assisting in isolation of UCB and AML MNCs. This project was funded by the National Plan for Science, Technology and Innovation (MAARIFAH) - King Abdulaziz City for Science and Technology (KACST), Kingdom of Saudi Arabia (Award No. 09-BIO693-03). The authors also, acknowledge with thanks Science and Technology Unit, King Abdulaziz University for technical support.

\section{References}

[1] Erba, H.P. (2010) Has There Been Progress in the Treatment of Older Patients with Acute Myeloid Leukemia? Best 
Practice \& Research Clinical Haematology, 23, 495-501. http://dx.doi.org/10.1016/j.beha.2010.09.012

[2] Stavropoulou, V., Brault, L. and Schwaller, J. (2010) Insights into Molecular Pathways for Targeted Therapeutics in Acute Leukemia. Swiss Medical Weekly, 140, w13068. http://dx.doi.org/10.4414/smw.2010.13068

[3] Adams, V.R. and Leggas, M. (2007) Sunitinib Malate for the Treatment of Metastatic Renal Cell Carcinoma and Gastrointestinal Stromal Tumors. Clinical Therapeutics, 29, 1338-1353. http://dx.doi.org/10.1016/j.clinthera.2007.07.022

[4] O’Farrell, A.M., Abrams, T.J., Yuen, H.A., Ngai, T.J., Louie, S.G., Yee, K.W., Wong, L.M., Hong, W., Lee, L.B., Town, A., Smolich, B.D., Manning, W.C., Murray, L.J., Heinrich, M.C. and Cherrington, J.M. (2003) SU11248 Is a Novel FLT3 Tyrosine Kinase Inhibitor with Potent Activity in Vitro and in Vivo. Blood, 101, 3597-3605. http://dx.doi.org/10.1182/blood-2002-07-2307

[5] O’Farrell, A.M., Foran, J.M., Fiedler, W., Serve, H., Paquette, R.L., Cooper, M.A., Yuen, H.A., Louie, S.G., Kim, H., Nicholas, S., Heinrich, M.C., Berdel, W.E., Bello, C., Jacobs, M., Scigalla, P., Manning, W.C., Kelsey, S. and Cherrington, J.M. (2003) An Innovative Phase I Clinical Study Demonstrates Inhibition of FLT3 Phosphorylation by SU11248 in Acute Myeloid Leukemia Patients. Clinical Cancer Research, 9, 5465-5476.

[6] Fiedler, W., Serve, H., Dohner, H., Schwittay, M., Ottmann, O.G., O'Farrell, A.M., Bello, C.L., Allred, R., Manning, W.C., Cherrington, J.M., Louie, S.G., Hong, W., Brega, N.M., Massimini, G., Scigalla, P., Berdel, W.E. and Hossfeld, D.K. (2005) A Phase 1 Study of SU11248 in the Treatment of Patients with Refractory or Resistant acute Myeloid Leukemia (AML) or Not Amenable to Conventional Therapy for the Disease. Blood, 105, 986-993. http://dx.doi.org/10.1182/blood-2004-05-1846

[7] Yee, K.W., Schittenhelm, M., O’Farrell, A.M., Town, A.R., McGreevey, L., Bainbridge, T., Cherrington, J.M. and Heinrich, M.C. (2004) Synergistic Effect of SU11248 with Cytarabine or Daunorubicin on FLT3 ITD-Positive Leukemic Cells. Blood, 104, 4202-4209. http://dx.doi.org/10.1182/blood-2003-10-3381

[8] Fiedler, W., Kayser, S., Kebenko, M., Janning, M., Krauter, J., Schittenhelm, M., Gotze, K., Weber, D., Gohring, G., Teleanu, V., Thol, F., Heuser, M., Dohner, K., Ganser, A., Dohner, H. and Schlenk, R.F. (2015) A Phase I/II Study of Sunitinib and Intensive Chemotherapy in Patients over 60 Years of Age with Acute Myeloid Leukaemia and Activating FLT3 Mutations. British Journal of Haematology, 169, 694-700. http://dx.doi.org/10.1111/bjh.13353

[9] Ailles, L.E., Gerhard, B., Kawagoe, H. and Hogge, D.E. (1999) Growth Characteristics of Acute Myelogenous Leukemia Progenitors That Initiate Malignant Hematopoiesis in Nonobese Diabetic/Severe Combined Immunodeficient Mice. Blood, 94, 1761-1772.

[10] Mahadevan, D. and List, A.F. (2004) Targeting the Multidrug Resistance-1 Transporter in AML: Molecular Regulation and Therapeutic Strategies. Blood, 104, 1940-1951. http://dx.doi.org/10.1182/blood-2003-07-2490

[11] Schlenk, R.F., Dohner, K., Krauter, J., Frohling, S., Corbacioglu, A., Bullinger, L., Habdank, M., Spath, D., Morgan, M., Benner, A., Schlegelberger, B., Heil, G., Ganser, A., Dohner, H. and German-Austrian Acute Myeloid Leukemia Study Group (2008) Mutations and Treatment Outcome in Cytogenetically Normal Acute Myeloid Leukemia. The New England Journal of Medicine, 358, 1909-1918. http://dx.doi.org/10.1056/NEJMoa074306

[12] Mrozek, K., Marcucci, G., Paschka, P., Whitman, S.P. and Bloomfield, C.D. (2007) Clinical Relevance of Mutations and Gene-Expression Changes in Adult Acute Myeloid Leukemia with Normal Cytogenetics: Are We Ready for a Prognostically Prioritized Molecular Classification? Blood, 109, 431-448. http://dx.doi.org/10.1182/blood-2006-06-001149

[13] Chou, T.-C. and Talalay, P. (1983) Analysis of Combined Drug Effects: A New Look at a Very Old Problem. Trends in Pharmacological Sciences, 4, 450-454. http://dx.doi.org/10.1016/0165-6147(83)90490-X

[14] Care, R.S., Valk, P.J., Goodeve, A.C., Abu-Duhier, F.M., Geertsma-Kleinekoort, W.M., Wilson, G.A., Gari, M.A., Peake, I.R., Lowenberg, B. and Reilly, J.T. (2003) Incidence and Prognosis of c-KIT and FLT3 Mutations in Core Binding Factor (CBF) Acute Myeloid Leukaemias. British Journal of Haematology, 121, 775-777. http://dx.doi.org/10.1046/j.1365-2141.2003.04362.x

[15] Lamba, G., Gupta, R., Lee, B., Ambrale, S. and Liu, D. (2012) Current Management and Prognostic Features for Gastrointestinal Stromal Tumor (GIST). Experimental Hematology \& Oncology, 1, 14. http://dx.doi.org/10.1186/2162-3619-1-14

[16] Teng, C.L., Yu, C.T., Hwang, W.L., Tsai, J.R., Liu, H.C., Hwang, G.Y. and Hsu, S.L. (2013) Effector Mechanisms of Sunitinib-Induced G1 Cell Cycle Arrest, Differentiation, and Apoptosis in Human Acute Myeloid Leukaemia HL60 and KG-1 Cells. Annals of Hematology, 92, 301-313. http://dx.doi.org/10.1007/s00277-012-1627-7

[17] Schnittger, S., Kohl, T.M., Haferlach, T., Kern, W., Hiddemann, W., Spiekermann, K. and Schoch, C. (2006) KIT-D816 Mutations in AML1-ETO-Positive AML Are Associated with Impaired Event-Free and Overall Survival. Blood, 107, 1791-1799. http://dx.doi.org/10.1182/blood-2005-04-1466

[18] Geyer, S., Zhao, J., Caroll, A.J., Bucci, D., Vij, R., Blum, W., Pardee, T., Wetzler, M., Stock, W., Bloomfield, C.D., Larson, R.A. and Stone, R.M. (2013) Adding The KIT Inhibitor Dasatinib (DAS) to Standard Induction and Consoli- 
dation Therapy for Newly Diagnosed Patients (pts) with Core Binding Factor (CBF) Acute Myeloid Leukemia (AML): Initial Results of the CALGB 10801 (Alliance) Study. Blood, 122, 357-357.

[19] Kulke, M.H., Lenz, H.J., Meropol, N.J., Posey, J., Ryan, D.P., Picus, J., Bergsland, E., Stuart, K., Tye, L., Huang, X., Li, J.Z., Baum, C.M. and Fuchs, C.S. (2008) Activity of Sunitinib in Patients with Advanced Neuroendocrine Tumors. Journal of Clinical Oncology, 26, 3403-3410. http://dx.doi.org/10.1200/JCO.2007.15.9020

[20] Cortes, J., Faderl, S., Estey, E., Kurzrock, R., Thomas, D., Beran, M., Garcia-Manero, G., Ferrajoli, A., Giles, F., Koller, C., O’Brien, S., Wright, J., Bai, S.A. and Kantarjian, H. (2005) Phase I Study of BMS-214662, a Farnesyl Transferase Inhibitor in Patients with Acute Leukemias and High-Risk Myelodysplastic Syndromes. Journal of Clinical Oncology, 23, 2805-2812. http://dx.doi.org/10.1200/JCO.2007.15.9020

[21] Cheng, F., Wang, L., Shen, Y., Xia, J., Chen, H., Jiang, Y. and Lu, M. (2016) Preclinical Evaluation of WYE-687, a mTOR Kinase Inhibitor, as a Potential Anti-Acute Myeloid Leukemia Agent. Biochemical and Biophysical Research Communications, 470, 324-330.

[22] Hu, S., Niu, H., Minkin, P., Orwick, S., Shimada, A., Inaba, H., Dahl, G.V., Rubnitz, J. and Baker, S.D. (2008) Comparison of Antitumor Effects of Multitargeted Tyrosine Kinase Inhibitors in Acute Myelogenous Leukemia. Molecular Cancer Therapeutics, 7, 1110-1120. http://dx.doi.org/10.1158/1535-7163.MCT-07-2218

[23] Youle, R.J. and Strasser, A. (2008) The BCL-2 Protein Family: Opposing Activities That Mediate Cell Death. Nature Reviews Molecular Cell Biology, 9, 47-59. http://dx.doi.org/10.1038/nrm2308

[24] Stander, B.A., Joubert, F., Tu, C., Sippel, K.H., McKenna, R. and Joubert, A.M. (2012) In Vitro Evaluation of ESE-15-ol, an Estradiol Analogue with Nanomolar Antimitotic and Carbonic Anhydrase Inhibitory Activity. PLoS ONE, 7, e52205. http://dx.doi.org/10.1371/journal.pone.0052205

[25] Knapper, S., Mills, K.I., Gilkes, A.F., Austin, S.J., Walsh, V. and Burnett, A.K. (2006) The Effects of Lestaurtinib (CEP701) and PKC412 on Primary AML Blasts: The Induction of Cytotoxicity Varies with Dependence on FLT3 Signaling in both FLT3-Mutated and Wild-Type Cases. Blood, 108, 3494-3503. http://dx.doi.org/10.1182/blood-2006-04-015487

[26] Patel, T., Gores, G.J. and Kaufmann, S.H. (1996) The Role of Proteases during Apoptosis. The FASEB Journal, 10, 587-597.

[27] Gerber, J.M., Smith, B.D., Ngwang, B., Zhang, H., Vala, M.S., Morsberger, L., Galkin, S., Collector, M.I., Perkins, B., Levis, M.J., Griffin, C.A., Sharkis, S.J., Borowitz, M.J., Karp, J.E. and Jones, R.J. (2012) A Clinically Relevant Population of Leukemic CD34 ${ }^{+}$CD38 ${ }^{-}$Cells in Acute Myeloid Leukemia. Blood, 119, 3571-3577. http://dx.doi.org/10.1182/blood-2011-06-364182

[28] Ran, D., Schubert, M., Taubert, I., Eckstein, V., Bellos, F., Jauch, A., Chen, H., Bruckner, T., Saffrich, R., Wuchter, P. and Ho, A.D. (2012) Heterogeneity of Leukemia Stem Cell Candidates at Diagnosis of Acute Myeloid Leukemia and Their Clinical Significance. Experimental Hematology, 40, 155-165.e1. http://dx.doi.org/10.1016/j.exphem.2011.10.005

[29] Goussetis, E., Theodosaki, M., Paterakis, G., Peristeri, J., Petropoulos, D., Kitra, V., Papassarandis, C. and Graphakos, S. (2000) A Functional Hierarchy among the CD34 ${ }^{+}$Hematopoietic Cells Based on in Vitro Proliferative and Differentiative Potential of AC133 ${ }^{+} \mathrm{CD} 34^{\text {Bright }}$ and AC133(dim/)-CD34+ Human Cord Blood Cells. Journal of Hematotherapy and Stem Cell Research, 9, 827-840. http://dx.doi.org/10.1089/152581600750062255

[30] Horn, P.A., Tesch, H., Staib, P., Kube, D., Diehl, V. and Voliotis, D. (1999) Expression of AC133, a Novel Hematopoietic Precursor Antigen, on Acute Myeloid Leukemia Cells. Blood, 93, 1435-1437. 